\title{
Stomach Irrigation Dosage Form
}

National Cancer Institute

\section{Source}

National Cancer Institute. Stomach Irrigation Dosage Form. NCI Thesaurus. Code C149952.

Liquid sterile preparation consisting of an aqueous solution intended for irrigation of the stomach. 